\section{Pre- and post-operative management of dental implant placement. Part 2: management of early-presenting complications}
IN BRIEF
- Highlights early presenting complications associated with dental implant placement.
- Provides practical recommendations for the management of post-operative haemorrhage following dental implant placement.
- Provides practical recommendations for the management of post-operative swelling following dental implant placement.

\author{
G. Bryce, ${ }^{* 1}$ D. I. Bomfim¹ and G. S. Bassi ${ }^{1}$
}

VERIFIABLE CPD PAPER

Despite morbidity factors that include pain and complications with healing, there is currently little available guidance regarding optimal pre-and post-operative protocols for dental implant placement. While the first paper of this two-part series discussed the management of post-operative pain, the second instalment reviews pre- and post-operative means of managing early complications associated with dental implant placement.

\section{INTRODUCTION}

Although the use of dental implants to restore edentulous sites is recognised as a safe and successful treatment modality, longitudinal outcome studies have identified the existence of associated early and late complications. ${ }^{1}$ Late complications are purported to arise three months post-operatively or following restoration and include; failure of the supported prosthesis, implant mucositis, perimplantitis and implant fracture. ${ }^{2,3}$ In contrast, early complications relate to those arising before osseointegration ${ }^{1}$ and are generally due to the inherent traumatic nature of the procedure to the mucosal and alveolar tissues and adjacent anatomical structures. These complications may include: swelling or bruising, prolonged bleeding, pain, neuro-sensory disturbance, mandibular fracture, infection or failure of the dental implant to osseointegrate. Presently there is surprisingly little consensus on the role that pre- and post-operative management of the surgical phase of dental implant placement plays on minimising the risk of these earlypresenting complications.

In the first paper of this two-part series, guidance on appropriate implant analgesic prescription was offered to the general dental practitioner. The second instalment aims to review the relevant dental literature and

'Restorative Dentistry, Restorative Department, Eastman Dental Hospital, 256 Gray's Inn Road, London, WC1X 8LD

${ }^{*}$ Correspondence to: Graeme Bryce

Email: graemebryce001@hotmail.com

\section{Refereed Paper}

Accepted 17 April 2014

DOI: 10.1038/sj.bdj.2014.702

${ }^{\circ}$ British Dental Journal 2014; 217: 171-176 provide recommendations on aspects of preand post-operative patient management that can be employed to reduce the risk of the following early complications:

1. Post-operative haemorrhage

2. Post-operative swelling

3. Post-operative infection and

optimisation of the osseointegration process

4. Neurosensory disturbance.

\section{POST-OPERATIVE HAEMORRHAGE}

Although vascular haemorrhage is commonly encountered during the operative phase of implant placement, ${ }^{4-6}$ late onset post-operative bleeds are also reported., The haemostatic process is driven by both direct- (physical injury) and indirect- (chemicals released by endothelial cells, pain receptor activation) stimulation of vascular endothelial smooth muscle. Smooth muscle contraction results in vascular constriction that reduces blood flow to the ruptured vessels with a subsequent reduction in blood loss. Concurrently, rapid platelet aggregation onto damaged endothelial cells forms a platelet plug that acts to temporarily seal the vessel walls. Reinforcement of this initial platelet plug occurs from both the deposition of further platelets and the formation of a fibrin meshwork, derived as an end-product of a clotting cascade of plasma proteins. ${ }^{9}$ Post-surgical haemorrhagic lesions may be classified by the extent of their surface diameter as follows; petechiae $(<2 \mathrm{~mm})$, purpura (2-10 $\mathrm{mm})$ and ecchymosis (>10 $\mathrm{mm})$.

General patient factors that may result in unexpected post-operative haemorrhage include underlying medical conditions (for example, clotting factor disorders, platelet disorders, blood dyscrasias) or prescription medications (for example, oral anticoagulants). Local factors that may result in unexpected post-operative bleeds include: the size of the surgical flap, ${ }^{9}$ the wearing off of the vasoconstrictor contained within the local anaesthetic, physical disruption of the clot or infection. With implant procedures, the fixture exerts positive pressure within the alveolar site, encouraging coagulum deposition and subsequent haemostasis. In uncomplicated implant placements, with no underlying medical history, post-operative bleeds are more likely to originate from the soft tissues and haemorrhagic lesions of both the intra- and extra-oral tissues are commonly encountered. ${ }^{2}$

Challenging dental implant placements, such as those associated with extensive bone grafting or sinus augmentation procedures, may increase the risk of both intra- and post-operative bleeds. The highly vascularised nature of the maxillary sinus ${ }^{10}$ explains why post-operative bleeding is commonly reported, ${ }^{11}$ in such cases presenting with ecchymosis or epistaxis (nose-bleed) that may alarm the uninformed patient. ${ }^{11}$

The majority of severe post-operative bleeds can be avoided by identifying medically-at-risk patients, via the taking of a thorough medical history and managing these cases appropriately. Post-operative instructions that detail common sense, preventative measures to reduce the risk of bleeding should include: the avoidance of strenuous exercise, maintenance of a soft diet and employing an oral hygiene regime that limits the risk of brushing-induced trauma to the surgical site. These instructions should also specify advice on the 
management of bleeding via the application of direct physical pressure using pressure packs such as; gauze dampened with chlorhexidine solution, in a manner that reduces the risk of trauma to the healing mucosa. The patient should be advised that pressure needs to be applied to the site for at least 30 minutes, before checking for clotting. ${ }^{9}$ Regarding post-operative nose bleeds, most are likely to be self-limiting but the patient should be provided with guidance on the management of epistaxis using established techniques such as head-tilting combined with the application of finger pressure to the nasal area for up to 20 minutes or the application of nasal compresses. ${ }^{12}$

Much of the advice regarding the clinical management of post-operative haemorrhage has been derived from studies that have assessed the management of post-extraction bleeding within patients undergoing warfarin therapy or suffering from bleeding disorders. Haemostasis can be achieved via a variety of means that include the use of: chemical agents (adrenaline-containing local anaesthetic, ferric sulphate, ${ }^{9}$ aluminium chloride [ $4.8 \%$ transexamic acid] $)^{13}$, clottinginducing sub-structures (oxidised cellulose, fibrin meshes, collagen gauzes) or physical measures (compression, pressure dressing, electrocautery or the placement of sutures). Effective haemorrhage control is situationdependent and, as no method has been shown to be optimal, the clinician should house a variety of materials for use in such an eventuality.

\section{POST-OPERATIVE SWELLING}

Placement of dental implants physically insults both mucosal and alveolar tissues, causing a classical acute inflammation process that aims to eradicate damaged tissues and prepare the site for healing/osseointegration. Swelling is a classical feature of acute inflammation that within the surgical phase of implant therapy may cause increased pain, loss of function or neural damage. ${ }^{14}$

Treatment provided to manage post-operative pain or swelling should not be at the expense of the healing process. Prevention of additional trauma to the wounded mucosa is important in reducing the extent and longevity of tissue swelling. Many of the postoperative care factors, discussed previously as part of managing haemostasis (such as soft-bristled tooth brushing regime), have additional benefits in reducing the risk of further trauma to the wound.

An additional aspect to consider is the importance of a correctly contoured and adjusted immediate restoration in influencing mucosal healing. If a fixed immediate restoration is to be placed, it is essential that both the occlusal and emergence profiles of the prosthesis are suitably adjusted to, respectively, avoid occlusal overload of the implant and facilitate optimal mucosal healing. If an immediate removable prosthesis is to be employed, appropriate adjustment should be undertaken to account for tissue swelling and to ensure that the prosthesis does not impinge upon the surgical site or interfere with the healing process.

Despite the established efficacy of nonsteroidal anti-inflammatory drugs (NSAIDs) and steroids in reducing post-operative swelling, ${ }^{15}$ some evidence suggests that these medications impose a negative effect on the osseointegration process. ${ }^{16,17}$ Cold compresses are an established method of managing post-operative swelling following oral surgical procedures ${ }^{18,19}$ and offer either an alternative or adjunct to prescribed medications. ${ }^{20}$ Cold therapy aims to cool the skin from $33{ }^{\circ} \mathrm{C}$ to $10-15^{\circ} \mathrm{C}$; a temperature that has been shown to reduce vascular flow, ${ }^{20,21}$ cellular inflammatory responses ${ }^{22}$ and also pain, ${ }^{23}$ while having a minimal effect in delaying the healing process. ${ }^{20}$ Forms of cold compresses include frozen home produce (frozen peas etc), commercial compresses (Instant Cold Pack ${ }^{\circledR}, K_{0 o l P a k}{ }^{\circledR}$ ) and individual clinician suggestions, such as the application of water-filled and frozen surgical gloves. Various recommendations for cold compress regimes exist and range from continuous applications ${ }^{24}$ to cycles of 10-30 minutes on/off. ${ }^{20}$ Given that the desired cooled tissue temperature is achieved by 10 minutes, ${ }^{25,26}$ and that there is some evidence to suggest that continuous cooling may result in peripheral nerve damage ${ }^{20}$ or frostbite injuries, ${ }^{27}$ a regime is recommended that consists applications of 10 minute exposures (with 20 minutes off) for the first 4 hours. The patient should also be advised that continuing cold compresses up to 48 hours post-operatively can further reduce swelling. ${ }^{20,28}$

\section{POST-OPERATIVE INFECTION AND OPTIMISATION OF THE OSSEOINTEGRATION PROCESS}

Osseointegration may be defined as the direct interface between an implant and bone without intervening soft tissue. Both osseointegration and good healing of the mucosal structures are required for dental implant placement to be successful. Although oral mucosa wounding undergoes phases of haemostasis, inflammation, proliferation and remodeling that are similar to dermal healing, the process is both faster and results in reduced scar tissue formation. ${ }^{29}$ Attempts to explain this rapid healing process have included; the action of salivary growth-promoting factors (EGF, NGF, TGF), ${ }^{30}$ and reduced levels of both inflammatory cell infiltrates and cytokines. ${ }^{31}$ Epithelialisation is normally re-established within 5 days, although some animal studies indicate that well approximated wounds may achieve point contact inhibition within 24 hours, ${ }^{31}$ facilitating a protective environment for osseointegration of the implant.

In theory, the risk of early implant failure due to infection is greatest before reepithelialisation of the wound. However, one-stage implant placement and restoration techniques have high success rates ${ }^{32,33}$ and this suggests that other protective mechanisms may support the osseointegration process. The densely-mineralised cortical bone layer provides excellent immediate stability $^{34}$ for the implant and the slow resorption/ remodeling of this layer may also provide additional protection to the main body of the implant (embedded within the cancellous bone), during the early healing phase. The underlying cancellous bone's greater vascularity permits rapid formation of new blood vessels and encourages the migration of mesenchymal cells which, in turn, act as precursors for the formation of woven bone (new immature bone) around the dental implant. Subsequently, cancellous bony turnaround is faster than its cortical counterpart and osseointegration of this portion of the implant occurs more rapidly. Despite the varying speeds of cortical and cancellous bony remodeling, osseointegration will generally be complete by 3-6 months post-placement. ${ }^{35-37}$ Early implant failures are characterised by a lack of osseointegration and fibrous tissue encapsulation of the implant. ${ }^{38}$ Various theories have been proposed to explain the causes of early implant failure and include; compromised healing capability of the host, insufficient primary implant stability and infection of the surgical site. ${ }^{38}$

Although infection of the implant site is infrequent, ${ }^{39}$ some general and local factors (Table 1) have been identified as contributors to increased risk of post-operative infection or early implant loss. Many of these factors may also compromise patients' healing responses and impact on implant stability.

The taking of a thorough medical history should identify patients with medical conditions, as detailed in Table 1. Diabetes mellitus is one condition that has been found to negatively impact osseointegration ${ }^{40}$ and increase the risk of implant failure. If appropriately controlled, Diabetes mellitus does not directly contra-indicate implant provision $^{40-42}$ although it is important that patients affected by this, and other conditions that negatively impact the osseointegration 


\section{Table 1 Factors contributing to implant failure}

\begin{tabular}{l|l}
\hline General factors & Local factors \\
\hline $\begin{array}{l}\text { Systemic medical conditions eg } \\
\text { - Diabetes-mellitus (poorly controlled) } \\
\text { - Osteoporosis } \\
\text { - Vitamin D deficiency }\end{array}$ & $\begin{array}{l}\text { Site of implant placement } \\
\text { - Maxilla } \\
\text { - Type IV (highly cancellous) bone }\end{array}$ \\
\hline $\begin{array}{l}\text { Medical therapy: } \\
\text { - Radiotherapy } \\
\text { - Chemotherapy }\end{array}$ & Bone augmentation \\
\hline Smoking & Poor oral hygiene \\
\hline Excessive alcohol consumption & $\begin{array}{l}\text { Operator factors: Poor surgical technique, ineffec- } \\
\text { tive cooling of surgical bur }\end{array}$ \\
\hline Malnutrition & \\
\hline
\end{tabular}

\begin{tabular}{|c|c|}
\hline General factors & Bisphosphonate specific factors \\
\hline Ethnicity (caucasian >black) & IV bisphosphonate \\
\hline Smoking & Longevity and frequency of treatment \\
\hline Diabetes mellitus (poorly controlled) & $\begin{array}{l}\text { Potency of bisphosphonate: } \\
\text { zoledronate }>\text { pamidronate }>\text { oral bisphosphonates }\end{array}$ \\
\hline \multicolumn{2}{|l|}{ Excessive alcohol intake } \\
\hline \multicolumn{2}{|l|}{ Longer term corticosteroid therapy } \\
\hline $\begin{array}{l}\text { Dental disease: } \\
\text { - Periodontal disease } \\
\text { - Periapical abscess }\end{array}$ & \\
\hline
\end{tabular}

process, are informed as to the increased risk of both early and delayed implant failure.

It is recognised that the placement of dental implants within patients that have undergone head and neck radiotherapy holds increased risk of both causing osteoradionecrosis $^{43,44}$ and failure of the implant to osseointegrate. ${ }^{45}$ Increased failure rates of dental implants have been found to be influenced by placement within the maxilla, higher radiation dose and longer durations between radiotherapy and implant placement. ${ }^{46}$

Recently, attention has been appropriated to both impaired osseointegration within osteoporotic patients and also the risk of bisphosphonate-induced osteonecrosis of the jaw. Bisphosphonate therapy may be delivered orally (to treat Paget's disease, osteoporosis, osteogenesis imperfecta) or intravenously (to treat skeletal complications associated with lung, breast and other cancers). It has been established that there is a relationship between osteonecrosis of the jaw, bisphosphonate therapy and dental extractions. Although no conclusive evidence exists to restrict the use of implants in either drug group, ${ }^{47-49}$ the consequences of osteonecrosis of the jaw are such that particularly careful preoperative assessment is warranted. The American Dental Association guidelines state that attention should be paid to the patient's systemic disease, the method of bisphosphonate delivery (oral versus intravenous), type of bisphosphonate (potency of drug), llongev(Table 2). It is generally reported that oral bisphosphonate therapy entails less risk of developing osteonecrosis $(0.7$ cases in 100,000$)$ than its IV counterpart. ${ }^{50}$ Guidelines on the dental management of patients taking frequent (4-12 times/year), potent IV bisphosphonates (zoledronic acid and pamidronates) suggest that elective traumatic procedures, such as dental implant placement, are not advised. ${ }^{51}$ Although guidelines on the dental management of patients taking oral bisphosphonates do not contra-indicate the undertaking of dental implant procedures, due attention should be paid to aforementioned osteonecrosis risk factors, especially for those who have been taking oral bisphosphonates for over 3 years and concomitantly with steroids such as prednisolone. ${ }^{49}$ Three-dimensional imaging, close liaison with the patient's medical team and informed consent are essential before embarking on dental implant therapy. ${ }^{51}$

Smoking imposes multiple effects on the oral mucosa both directly (via vasoconstriction, increased temperature and the toxic effects of by-products such as; nicotine, carbon monoxide, hydrogen cyanide) and indirectly (via inhibition of inflammatory ity of past- or ongoing- therapeutic regime cell mechanisms). ${ }^{52,53}$ Subsequently, smokers are associated with increased risk of post-operative infection and failure of both grafting procedures and implant osseointegration..$^{53}$ Ideally, smoking cessation should be undertaken at least 3 months before surgery, when the negative effects of smoking on implant success have been shown to be reduced. ${ }^{54}$ In cases where smoking cessation is not feasible, some of the direct effects of smoking can be reduced if the patient can be persuaded to cease smoking 24 hours preoperatively and for 5 days post-operatively. ${ }^{55}$

Effective pre- and post-operative plaque control has been identified as an important factor in improving the outcome of periodontal surgery. ${ }^{56}$ While effective oral hygiene should be established before embarking on dental implant provision, maintenance of plaque control post-operatively is complicated by the risk of tooth-brushing trauma to the healing soft tissues. The use of softbristled brushes (for example, Chirugia", Vitus, Barcelona, Spain) for post-operative plaque control has been suggested as an effective means of managing plaque control around the surgical site, while minimising the risk of trauma to the wound ${ }^{57}$ Except for cases that have involved bone augmentation procedures (where delayed suture removal may be necessary), suture removal should be undertaken 7 days post-operatively, to allow sufficient time for flap stabilisation but before the build-up of plaque deposits. ${ }^{58}$

Mouthwashes such as saline, ${ }^{59,60}$ povidone iodine ${ }^{61}$ cetylpyridinium chloride ${ }^{62}$ and chlorhexidine gluconate ${ }^{63}$ have been shown to positively influence healing within oral surgical disciplines. In particular, the use of chlorhexidine gluconate (CHX) solution has achieved popularity due to its broad-spectrum antimicrobial effects (exerting its action via disruption of bacterial membrane activity), ${ }^{64}$ substantivity properties that facilitate continued anti-microbial effect for up to 4 hours post usage, ${ }^{65}$ limited bacterial resistance to the medicament and minimal side-effects on the healing process. Given that bacterial contamination of the implant at placement may result in biofilm formation ${ }^{66}$ and lead to early failure, ${ }^{38}$ decontamination of the surgical field is a sensible precaution for any operative procedure. A 1 min pre-operative rinse of $0.2 \%$ CHX is recommended as this has been demonstrated to reduce the oral bacterial load by $97 \% .{ }^{67}$ Three times daily mouth rinses of $0.2 \%$ CHX for 7 days (or until the sutures are removed) is also advised as an effective adjunct for post-implant placement wound care..$^{63}$

\section{The use of antibiotics}

A variety of prophylactic and post-operative antibiotic regimes have been evaluated to 


\begin{tabular}{|c|c|c|c|}
\hline & Pre-operative & Post-operative & Complications \\
\hline $\begin{array}{l}\text { Management of } \\
\text { haemorrhage }\end{array}$ & $\begin{array}{l}\text { Consent: } \\
\text { Likelihood of post-operative bruising, } \\
\text { periorbital ecchymosis } \\
\text { Clinical: } \\
\text { Comprehensive medical history to rule out } \\
\text { haemorrhagic conditions and medications. } \\
\text { Pre-operative assessment with 3D imaging } \\
\text { where appropriate }\end{array}$ & $\begin{array}{l}\text { Instructions: } \\
\text { Avoidance of exercise } \\
\text { Prevention of clot-disruption (including } \\
\text { appropriate oral hygiene methods) } \\
\text { Management of post-operative bleeds } \\
\text { using pressure. CHX-soaked gauze for } \\
30 \text { minutes } \\
\text { - }\end{array}$ & $\begin{array}{l}\text { Instructions: } \\
\text { Management of epistaxis via head tilting/ } \\
\text { nasal compression. } \\
\text { Clinical: } \\
\text { Post-operative haemorrhage protocol. } \\
\text { 1. Minor bleeds: } \\
\text { Assessment of site, placement of additional } \\
\text { LA with vasoconstrictor, application of } \\
\text { pressure via dampened gauze onto the } \\
\text { bleeding site. } \\
\text { 2. Moderate - severe bleeds: } \\
\text { As for minor bleeds + placement of addi- } \\
\text { tional sutures, haemostatic agents. Use of } \\
\text { gauze dampened with transexamic acid. }\end{array}$ \\
\hline $\begin{array}{l}\text { Management } \\
\text { of swelling }\end{array}$ & $\begin{array}{l}\text { Consent: } \\
\text { Likelihood of swelling, pain and reduced } \\
\text { function }\end{array}$ & $\begin{array}{l}\text { Instructions: } \\
\text { Cold compress } 10 \text { mins on/20 mins off } \\
\text { for } 4 \text { hours. Advise patient that further } \\
\text { reduction in swelling can be achieved by } \\
\text { repeated applications throughout first } \\
48 \text { hours. } \\
\text { Clinical: } \\
\text { NSAIDs as per paper one. }\end{array}$ & $\begin{array}{l}\text { Clinical: } \\
4 \text { mg dexamethasone daily for } 7 \text { days }\end{array}$ \\
\hline $\begin{array}{l}\text { Reduction of risk } \\
\text { of post-operative } \\
\text { infection and } \\
\text { optimisation of } \\
\text { osseointegration } \\
\text { process }\end{array}$ & $\begin{array}{l}\text { Consent: } \\
\text { Low risk of post-operative infection and } \\
\text { high success rates in uncomplicated } \\
\text { implant cases. Discuss factors that increase } \\
\text { risk of failure/ infection. } \\
\text { Instructions: } \\
\text { Smoking cessation } 3 \text { months before place- } \\
\text { ment. As a minimum, } 24 \text { hours pre- and } \\
5 \text { days post-operatively. } \\
\text { Medical history. } \\
\text { Liaison with GMP to determine stability } \\
\text { of diabetes mellitus, other conditions and } \\
\text { therapies (for example, bisphosphonate or } \\
\text { similar). } \\
\text { Clinical: } \\
2 \mathrm{~g} \text { or } 3 \mathrm{~g} \text { amoxicillin } 1 \text { hour } \\
\text { pre-operativelyl } \\
600 \text { mg clindamycin } 1 \text { hour pre-operatively } \\
\text { in penicillin intolerant patients } \\
1 \text { min rinse of CHX mouthwash }\end{array}$ & $\begin{array}{l}\text { Instructions: } \\
\text { CHX mouth rinse } 3 \text { times daily for } 7 \text { days or } \\
\text { until sutures are removed. } \\
\text { The use of soft-bristled brushes to assist } \\
\text { plaque control within the surgical site } \\
\text { (may be commenced post-operatively and } \\
\text { continued until mucosal healing is judged } \\
\text { to be complete). } \\
\text { Additional advice for sinus floor elevation } \\
\text { procedures: } \\
\text { Avoidance of swimming, flying for at least } \\
2 \text { weeks } \\
\text { Not to stifle sneezes for } 2 \text { weeks } \\
\text { No nose-blowing for } 2 \text { weeks }\end{array}$ & $\begin{array}{l}\text { Clinical: } \\
\text { Amoxicillin } 500 \text { mg TDS } 7 \text { days for } 10 \text { days } \\
300 \text { mg Clindamycin TDS } 7 \text { days for } 10 \text { days } \\
\text { (for penicillin sensitive patients). } \\
\text { Additional measures for sinus floor } \\
\text { elevation: } \\
\text { Prescription of antihistamine tablets and/or } \\
\text { nasal sprays for patients suffering from hay } \\
\text { fever or Type I Hypersensitivities. }\end{array}$ \\
\hline $\begin{array}{l}\text { Neurosensory } \\
\text { disruption }\end{array}$ & $\begin{array}{l}\text { Clinical: } \\
\text { Pre-operative evaluation including 3D } \\
\text { imaging where necessary }\end{array}$ & $\begin{array}{l}\text { Instructions: } \\
\text { Need to report altered sensation to clinic } \\
\text { Prescription of dexamethasone (6-8 mg } \\
\text { daily for } 7 \text { days) } \\
\text { NSAIDs as per paper one }\end{array}$ & $\begin{array}{l}\text { Clinical: } \\
\text { Reversal of implant away from neurovas- } \\
\text { cular structure (if complications recognised } \\
\text { at early stage) } \\
\text { Explantation of implant }\end{array}$ \\
\hline
\end{tabular}

assess their effectiveness in reducing the rate of post-implant placement infections and optimising the osseointegration process. Although the results of individual studies vary with regard to conclusions drawn, a recent Cochrane review of the literature concluded that the provision of a $2 \mathrm{~g}$ preoperative dose of amoxicillin may improve the success rate of osseointegration. ${ }^{68}$ For patients who suffer from penicillin intolerance or allergy, a $600 \mathrm{mg} 1$ hour pre-operative dose of clindamycin is recommended. ${ }^{69}$

When bone grafting or sinus augmentation procedures are required to facilitate implant placement there is greater risk of site infection and antibiotic regimes, consisting of either amoxicillin $500 \mathrm{mg}$ TDS or clindamycin $300 \mathrm{mg}$ TDS for 10 days, have been advocated. ${ }^{11,70}$ Patients who have undergone maxillary sinus floor elevation should be advised not to undertake activities that may apply additional pressure to the maxillary sinus such as; the avoidance of flying or swimming for two weeks post-operatively and to not internalise sneezes (patients that suffer seasonal hay fever, or from similar allergic-type reactions that induce sneezing, may require the prescription of antihistamine tablets and nasal sprays). If infection of the surgical site is encountered, osseointegration of the fixture will be impaired and explantation of the implant may be necessary.
When prescribing antibiotics, it is important that the clinician weighs the potential benefits of improved implant success against the risk of well documented complications that may include: direct toxicity (nausea, vomiting, diarrhoea), haematological complications (neutropenia, thrombocytopenia), anaphylactic reaction, microbial flora disruptions, nephrotoxicity, drug interactions and acquired bacterial resistance to antimicrobials. ${ }^{71}$

\section{NEUROSENSORY DISRUPTION}

The placement of dental implants can result in damage to both maxillary and mandibular branches of the trigeminal nerve that include 
the inferior alveolar nerve, the mental nerve, the lingual nerve, the incisive nerve and the infra-orbital nerve. Neural trauma may occur both directly, due to section during the surgical procedure, or indirectly, as a result of nerve compression by either the implant or subsequent inflammatory process. Studies indicate that a range of post-operative implant-induced neurosensory disruption exists between 0\%-44\%., ${ }^{2,72}$ Nerve injuries are commonly classified by the severity of neuron axon damage and encompass neuropraxia (structure of axon intact), axonotmesis (some axon damage but nerve structure intact) and neuromesis (structural damage of the nerve). The extent of the nerve injury will normally dictate the extent of the symptoms encountered and may present with paraesthesia (altered sensation), dysaesthesia (unpleasant altered sensation) or anaesthesia (loss of sensation). ${ }^{73}$ Although cases of idiopathic facial pain are reported following implant placement, ${ }^{74}$ the incidence of such events is likely to be low.

A thorough pre-operative assessment that employs appropriate 3D imaging and planning can reduce the risk of neural trauma and subsequent neurosensory disruption. It has been advised that, when planning implant placement within the mandible, a minimum safety margin of $2 \mathrm{~mm}$ should be left between the coronal aspect of the nerve and dental implant. ${ }^{75}$ The patient should be appropriately forewarned of neurosensory complications as part of the consent process.

In the event of altered sensation, the patient should be informed of the need to contact the clinician immediately. A comprehensive post-operative assessment should ascertain the extent of the nerve injury (using both nociceptive and mechanoceptive tests) ${ }^{76}$ and whether the injury has been caused by direct or indirect trauma. In cases of mild neurosensory disruption, the use of NSAIDs (600 mg ibuprofen QDS) ${ }^{77}$ and steroids (6-8 mg dexamethasone daily), ${ }^{72}$ to reduce inflammation and subsequently pressure on the nerve, has been suggested. In addition, the use of steroids may inhibit peripheral neural axon sprouting and reduce the risk of the development of dysaesthesia. ${ }^{72,78,79} \mathrm{In}$ cases where neuromesis is suspected, early reversal of the implant away from the nerve or explantation of the implant, with referral of the patient to a neurosurgical specialist, is advised.$^{80}$

\section{CONCLUSION}

In general, many of the complications encountered within dental implant placement can be prevented by sound pre-operative assessment and intra-operative technique. It is essential that a robust consent process informs the patient of possible complications and that they are also prepared to manage expected problems with the provision of comprehensive post-operative instructions, medications and medicaments. A summary of these recommendations is provided in Table 3.

1. Albrektsson T, Zarb G, Worthington P, Eriksson A R. The long-term efficacy of currently used dental implants: a review and proposed criteria of success. Int J Oral Maxillofac Implants 1986; 1: 11-25.

2. Goodacre C J, Bernal G, Rungcharassaeng K, Kan J Y. Clinical complications with implants and implant prostheses. J Pros Dent 2003; 90: 121-132.

3. Jung R E, Pjetursson B E, Glauser R, Zembic A, Zwahlen M, Lang N P. A systematic review of the 5 -year survival and complication rates of implantsupported single crowns. Clin Oral Implants Res 2008; 19: 119-130.

4. Roos J, Sennerby L, Lekholm U, Jemt T, Gröndahl K, Albrektsson T. A qualitative and quantitative method for evaluating implant success: a 5-year retrospective analysis of the Branemark implant. Int J Oral Maxillofac Implants 1997; 12: 504-514.

5. Jemt $T$, Laney W R, Harris D et al. Osseointegrated implants for single tooth replacement: a 1-year report from a multicentre prospective study. Int J Oral Maxillofac Implants 1991; 6: 29-36.

6. Kalpidis C D, Konstantinidis A B. Critical haemorrhage in the floor of the mouth during implant placement in the first mandibular premolar position: a case report. Implant Dent 2005; 14: 117-124.

7. Laboda G. Life-threatening haemorrhage after placement of an endosseous implant: report of case. J Am Dent Assoc 1990; 121: 599-600.

8. Isaacson T J. Sublingual haematoma formation during immediate placement of mandibular endosseous implants. J Am Dent Assoc 2004; 135: 168-172.

9. Israels S, Schwetz N, Boyar R, McNicol A. Bleeding disorders: characterization, dental considerations and management. J Can Dent Assoc 2006; 72: 827.

10. Rosano G, Taschieri S, Gaudy J F, Del Fabbro M. Maxillary sinus vascularization: a cadaveric study. J Craniofac Surg 2009; 20: 940-943.

11. Schwartz-Arad D, Herzberg R, Dolev E. The prevalence of surgical complications of the sinus graft procedure and their impact on implant survival. J Periodontol 2004; 75: 511-516.

12. Kucik C J, Clenney T. Management of epistaxis. Am Fam Physician 2005; 71: 305-311.

13. Borea G, Montebugnoli L, Capuzzi P, Magelli C. Tranexamic acid as a mouthwash in anticoagulanttreated patients undergoing oral surgery: an alternative method to discontinuing anticoagulant therapy. Oral Surg Oral Med Oral Path 1993; 75: 29-31.

14. Arisan V, Karabuda C Z, Ozdemir T. Implant surgery using bone-and mucosa-supported stereolithographic guides in totally edentulous jaws: surgical and post-operative outcomes of computer-aided vs. standard techniques. Clin Oral Implants Res 2010; 21: 980-988.

15. Olstad O A, Skjelbred P. The effects of indoprofen vs paracetamol on swelling, pain and other events after surgery. Int J Clin Pharmacol Ther Toxicol 1986; 24: 34-38.

16. Trancik T, Mills W, Vinson N. The effect of indomethacin, aspirin and ibuprofen on bone ingrowth into a porous-coated implant. Clin Orthop Relat Res 1989; 249: 113-121.

17. Ribeiro FV, César-Neto J B, Nociti F H Jr et al. Selective cyclooxygenase-2 inhibitor may impair bone healing around titanium implants in rats. J Periodontol 2006; 77: 1731-1735.

18. Tsesis I, Fuss Z, Lin S, Tilinger G, Peled M. Analysis of postoperative symptoms following surgical endodontic treatment. Quintessence Int 2003 34: 756-760.

19. Bleakley C, McDonough S, MacAuley D. Update for chapter 4: what is the role of ice in the treatment of acute soft tissue injuries? Jordanstown: University of Ulster. Online update available at http://www. federaljack.com/ebooks/My\%20collection\%20of\%20
medical\%20books,\%20208\%20Books\%20(part\%20 1\%20of\%203)/Evidence\%20Based\%20Sports\%20 Medicine/ch4_update.pdf (accessed June 2014).

20. Greenstein G. Therapeutic efficacy of cold therapy after intraoral surgical procedures: a literature review. J Periodonto/ 2007; 78: 790-800.

21. Lee $H$, Natsui $H$, Akimoto $T$, Yanagi $K$, Ohshima $N$, Kono I. Effects of cryotherapy after contusion using real-time intravital microscopy. Med Sci Sport Exerc 2005; 37: 1093-1098.

22. Zachariassen K E. Hypothermia and cellular physiology. Arctic Med Res 1991; 50: 13-17.

23. Hocutt J E, Jaffe R, Rylander C R, Beebe J K. Cryotherapy in ankle sprains. Am J Sports Med 1982 10: 316-319.

24. Van der Westhuijzen A, Becker P, Morkel J, Roelse $J$ A. A randomized observer blind comparison of bilateral facial ice pack therapy with no ice therapy following third molar surgery. Int J Oral Maxillofac Surg 2005; 34: 281-286.

25. LaVelle B E, Snyder M. Differential conduction of cold through barriers. J Adv Nurs 1985; 10: 55-61.

26. Merrick M A, Knight $K L$, Ingersoll C D, Potteiger $J$ A. The effects of ice and compression wraps on intramuscular temperatures at various depths. J Athl Train 1993; 28: 236-245.

27. Draper D, Knight K L. Case review: mild frostbite caused by gel pack application. Int J Athlet Train Ther 2010; 15.

28. McDonald W, Guthrie Jr J. Cryotherapy in the postoperative setting. J Foot Surg 1985; 24: 438.

29. Sciubba J J, Waterhouse J P, Meyer J. A fine structural comparison of the healing of incisional wounds of mucosa and skin. J Oral Path Med 1978; 7: 214-227.

30. Shah $M$, Foreman D M, Ferguson M. Neutralisation of TGF-beta 1 and TGF-beta 2 or exogenous addition of TGF-beta 3 to cutaneous rat wounds reduces scarring. J Cell Sci 1995; 108: 985-1002.

31. Szpaderska A, Zuckerman J, DiPietro L. Differentia injury responses in oral mucosal and cutaneous wounds. J Dent Res 2003; 82: 621-626.

32. Szmukler-Moncler $S$, Piattelli $A$, Favero $G A$, Dubruille J H. Considerations preliminary to the application of early and immediate loading protocols in dental implantology. Clin Oral Implants Res 2000; 11: 12-25.

33. Ericsson I, Randow K, Nilner K, Peterson A. Early functional loading of Brånemark dental implants: 5-year clinical follow-up study. Clin Implant Dent Relat Res 2000; 2: 70-77.

34. Le Guéhennec L, Soueidan A, Layrolle P, Amourig Y. Surface treatments of titanium dental implants for rapid osseointegration. Dent Mater 2007; 23: 844-854.

35. Brånemark P I, Hansson B O, Adell R et al. Osseointegrated implants in the treatment of the edentulous jaw. Experience from a 10-year period. Scand J Plast Reconstr Surg Suppl 1977; 16: 1-132.

36. Albrektsson T, Brånemark P I, Hansson $\mathrm{H}$ A, Lindström J et al. Osseointegrated titanium implants: Requirements for ensuring a long-lasting, direct bone-to-implant anchorage in man. Acta Orthop Scand 1981; 52: 155-170.

37. Zarb G, Schmitt A. The longitudinal clinical effectiveness of osseointegrated dental implants: the Toronto study. Part I: surgical results. J Prosthet Dent 1990; 63: 451-457.

38. Esposito M, Thomsen P, Ericson L E, Lekholm U. Histopathologic observations on early oral implant failures. Int J Oral Maxillofac Implants 1999; 14: 798-810.

39. Dent C D, Olson J W, Farish S E et al. The influence of preoperative antibiotics on success of endosseous implants up to and including stage II surgery: a study of 2: 641 implants. J Oral Maxillofac Surg 1997; 55(12 Suppl 5): 19.

40. Javed F, Romanos G E. Impact of diabetes mellitus and glycaemic control on the osseointegration of dental implants: a systematic literature review. J Periodontol 2009; 80: 1719-1730.

41. Balshi T J, Wolfinger $G \mathrm{~J}$. Dental implants in the diabetic patient: a retrospective study. Implant Dent 1999; 8: 355-359.

42. Bornstein M M, Cionca N, Mombelli A. Systemic conditions and treatments as risks for implant therapy. 
Int J Oral Maxillofac Implants 2009; 24: 12-27.

43. Reuther T, Schuster T, Mende U, Kübler A.

Osteoradionecrosis of the jaws as a side effect of radiotherapy of head and neck tumour patients-a report of a thirty year retrospective review. Int J Oral Maxillofac Surg 2003; 32: 289-295.

44. Nabil S, Samman N. Incidence and prevention of osteoradionecrosis after dental extraction in irradiated patients: a systematic review. Int J Oral Maxillofac Surg 2011; 40: 229-243.

45. Urken M L, Buchbinder D, Costantino P D et al. Oromandibular reconstruction using microvascular composite flaps: report of 210 cases. Arch Otolaryngol Head Neck Surg 1998; 124: 46-55.

46. Granström G. Osseointegration in irradiated cancer patients: an analysis with respect to implant failures. J Oral Maxillofac Surg 2005; 63: 579-585.

47. Jacobsen $C$, Metzler P, Rössle M, Obwegeser J, Zemann W, Grätz K W. Osteopathology induced by bisphosphonates and dental implants: clinical observations. Clin Oral Investig 2013; 17: 167-175.

48. Chadha G K, Ahmadieh A, Kumar S K, Sedghizadeh P P. Osseointegration of dental implants and osteonecrosis of the jaw in patients treated with bisphosphonate therapy: A systematic review. J Oral Implantol 2012; epub ahead of print.

49. Grant B T, Amenedo C, Freeman K, Kraut R A. Outcomes of placing dental implants in patients taking oral bisphosphonates: a review of 115 cases. J Oral Maxillofac Surg 2008; 66: 223-230.

50. Marx R E, Sawatari Y, Fortin M, Broumand V. Bisphosphonate-induced exposed bone (osteonecrosis/osteopetrosis) of the jaws: risk factors, recognition, prevention, and treatment. J Oral Maxillofac Surg 2005; 63: 1567-1575.

51. Ruggiero S L, Dodson T B, Assael L A et al. American Association of Oral and Maxillofacial Surgeons position paper on bisphosphonate-related osteonecrosis of the jaw-2009 update. Aust Endo 2009; 35: 119-130.

52. César-Neto J B, Duarte P M, Sallum E A, Barbieri D, Moreno $\mathrm{H}$ Jr, Nociti F H Jr. A comparative study on the effect of nicotine administration and cigarette smoke inhalation on bone healing around titanium implants. J Periodontol 2003; 74: 1454-1459.

53. Levin L, Schwartz-Arad D. The effect of cigarette smoking on dental implants and related surgery. Implant Dent 2005; 14: 357-363.

54. Bain C A. Smoking and implant failure-benefits of a smoking cessation protocol. Int J Oral Maxillofac Implants 1996; 11: 756-759.

55. Morozumi T, Kubota T, Sato T, Okuda K, Yoshie H. Smoking cessation increases gingival blood flow and gingival crevicular fluid. J Clin Periodonto/ 2004; 31: 267-272.

56. Nyman S, Rosling B, Lindhe J. Effect of professional tooth cleaning on healing after periodontal surgery. J Clin Periodontol 1975; 2: 80-86.

57. Heitz F, Heitz-Mayfield L, Lang N. Effects of postsurgical cleansing protocols on early plaque control in periodontal and/or periimplant wound healing. J Clin Periodontol 2004; 31: 1012-1018.

58. Kim J S, Shin S I, Herr Y, Park J B, Kwon Y H, Chung $\mathrm{J} H$. Tissue reactions to suture materials in the oral mucosa of beagle dogs. J Period Implant Sci 2011; 41: 185-191.

59. Newman P, Addy M. Comparison of hypertonic saline and chlorhexidine mouthrinses after the inverse bevel flap procedure. J Periodonto/ 1982; 53: 315-318.

60. Osunde O, Adebola R, Adeoye J B, Bassey G O. Comparative study of the effect of warm saline mouth rinse on complications after dental extractions. Int J Oral Maxillofac Surg 2014; 43: 649-653.

61. Altonen M, Saxén L, Kosunen T, Ainamo J. Effect of two antimicrobial rinses and oral prophylaxis on preoperative degerming of saliva. Int J Oral Surg 1976; 5: 276-284

62. Huffman G G, Wood W H, Hausler W J, Jensen J. The effects of preoperative rinsing with cetylpyridinium chloride on bacteraemia associated with the surgical removal of impacted third molars. Oral Surg Oral Med Oral Pathol 1974; 38: 359-366.

63. Francetti L, Del Fabbro M D, Basso M, Testori $T$, Taschieri S, Weinstein R. Chlorhexidine spray versus mouthwash in the control of dental plaque after implant surgery. J Clin Periodontol 2004 31: 857-862.

64. Addy M, Wright R. Comparison of the in vivo and in vitro antibacterial properties of povidone iodine and chlorhexidine gluconate mouthrinses. J Clin Periodontol 1978; 5: 198-205.

65. Toljanic J A, Hagen J C, Takahashi Y, Shapiro R D. Evaluation of the substantivity of a chlorhexidine oral rinse in irradiated head and neck cance patients. J Oral Maxillofac Surg 1992; 50: 1055-1059.

66. Mombelli A. Microbiology of the dental implant. Adv
Denl Res 1993; 7: 202-206.

67. Veksler A E, Kayrouz G A, Newman M G. Reduction of salivary bacteria by pre-procedural rinses with chlorhexidine $0.12 \%$. J Periodontol 1991; 62: 649-651.

68. Esposito M, Grusovin M G, Loli V, Coulthard P, Worthington $\mathrm{H} \mathrm{V}$. Does antibiotic prophylaxis at implant placement decrease early implant failures? A Cochrane systematic review. Eur J Oral Implantol 2010: 3: 101-110.

69. Binahmed A, Stoykewych A, Peterson L. Single preoperative dose versus long-term prophylactic antibiotic regimens in dental implant surgery. Int J Oral Maxillofac Implant 2005; 20: 115-117.

70. Bruggenkate C M, Bergh J P. Maxillary sinus floor elevation: a valuable pre-prosthetic procedure. Periodontol 2000 1998; 17: 176-182.

71. Cunha B A. Antibiotic side effects. Med Clin North Am 2001; 85: 149-185.

72. Misch $C E$, Resnik R. Mandibular nerve neurosensory impairment after dental implant surgery: management and protocol. Implant Dent 2010; 19: 378-386.

73. Merksey $H$, Bogduk N. Classification of chronic pain Seattle: Int Assoc Study Pain Press 1994; 194: 210.

74. Queral-Godoy E, Vazquez-Delgado E, Okeson J P, Gay-Escoda C. Persistent idiopathic facial pain following dental implant placement: a case report. Int J Oral Maxillofac Implants 2006; 21: 136-140.

75. Greenstein G, Tarnow D. The mental foramen and nerve: clinical and anatomical factors related to dental implant placement: a literature review. $J$ Periodontol 2006; 77: 1933-1943.

76. Day J D, Fukushima T. The surgical management of trigeminal neuromas. Neurosurgery 1998 ; 42: 233-240.

77. Kraut R A, Chahal O. Management of patients with trigeminal nerve injuries after mandibular implant placement. J Am Dent Assoc 2002; 133: 1351-1354

78. Hong D, Byers M R, Oswald R J. Dexamethasone treatment reduces sensory neuropeptides and nerve sprouting reactions in injured teeth. Pain 1993; 55: 171-181.

79. Misch C E, Moore P. Steroids and the reduction of pain, oedema and dysfunction in implant dentistry. Int J Oral Implantol 1989; 6: 27-31.

80. Khawaja N, Renton T. Case studies on implant removal influencing the resolution of inferior alveolar nerve injury. Br Dent J 2009; 206: 365-370. 